Article

\title{
The Effect of Rural Buildings on Landscape Fragmentation in Natura 2000 Sites: A Case Study in Sardinia
}

\author{
Antonio Ledda ${ }^{1}\left(\mathbb{D}\right.$, Vittorio Serra ${ }^{2} \mathbb{D}$ and Andrea De Montis ${ }^{1,2, *(\mathbb{C}}$ \\ 1 Dipartimento di Agraria, University of Sassari, Viale Italia 39, 07100 Sassari, Italy \\ 2 Department of Civil and Environmental Engineering and Architecture, University of Cagliari, via Marengo 2, \\ 09123 Cagliari, Italy \\ * Correspondence: andreadm@uniss.it; Tel.: +39-079-229242
}

Received: 30 July 2019; Accepted: 23 August 2019; Published: 28 August 2019

\begin{abstract}
Landscape fragmentation (LF) is the process where habitat patches tend to become smaller and more isolated over time. It is mainly due to human activities and affects habitats, biodiversity, ecosystem balance, and ecological networks. Transport and mobility infrastructures and urbanized areas-also in the form of suburban and rural sprawl — contribute to LF and can be localized close to (or included in) Natura 2000 sites (N2000 sites). N2000 sites are set according to the Habitats and Birds Directives and consist of special protection areas, sites of community importance, and special areas of conservation, where LF may threaten habitat quality and species survival and dispersal. Then, new rules and planning approaches are called for defining effective protection measures. The knowledge of the context appears to be a priority to achieve such aims. Therefore, this study focuses on LF in N2000 sites. We apply the rural buildings fragmentation index (RBFI) and the effective mesh density (Seff) in six landscape units in Sardinia (Italy). Then, we report on the least and the most fragmented N2000 sites and assess if there is correlation between RBFI and Seff. In this study, RBFI and Seff provide not trivial outcomes, as they are weakly and positively correlated.
\end{abstract}

Keywords: Italy; Sardinia; rural buildings; protection and conservation areas; landscape fragmentation; habitat loss; rural buildings fragmentation index (RBFI); effective mesh density (Seff); comparative analysis

\section{Introduction}

Human actions are acknowledged as major drivers affecting landscape quality. Deforestation, transport and mobility infrastructures (TMIs), and land conversion for agricultural, industrial, and urban uses influence habitat quality, ecosystems balance, and biodiversity [1,2]. Harmful effects include landscape fragmentation (LF) - i.e., the process where habitat patches tend to become smaller and more isolated [1]. LF characterizes urbanized contexts, where TMIs [1,3,4] and urban settlement [5] trigger habitat loss and contribute in reducing size and isolating habitat patches. LF affects flora and wild fauna [6] in both the long and short run and can lead to population extinction. Ecological networks are also affected by urbanized areas $[7,8]$, in that buildings and TMIs are elements that contribute to soil consumption or, in other terms, to natural habitat (con-)diversion for human uses.

Conservation of habitats has been acknowledged as a matter of primary importance by the scientific community for a long while [9-11]. In response to such a need, the Council of the European Communities enacted the 'Habitat Directive' (Directive 92/43/EEC; [12]), which focuses mainly on the protection of biodiversity and the preservation of natural habitats for wild flora and fauna in the European continent. A cornerstone of this act is the establishment of the Natura 2000 (hereafter noted as 
N2000) network, which is projected to include special conservation areas and special protection areas, the latter one is defined according to the 'Birds Directive' (Directive 2009/147/EC; [13]). As a whole, sites of community importance (SCIs), special areas of conservation (SACs), and special protection areas (SPAs) constitute N2000 sites. According to the N2000 barometer statistics (release version End2018-15 March 2019), N2000 land areas extend for more than 784,000 km², while N2000 marine areas for more than $551,000 \mathrm{~km}^{2}$ [14]. In Italy, N2000 land and marine areas extend, respectively, for more than $57,000 \mathrm{~km}^{2}$ and $6800 \mathrm{~km}^{2}$. In Italy, N2000 network includes more than 2600 sites. As for the island of Sardinia, 56 SACs have been set according to the Decree of the Italian Ministry of the Environment [15], and N2000 sites are receiving growing attention by scholars [16-18].

N2000 sites most of the times include rural areas. Rural and peri-urban contexts are characterized by rural buildings, which are settled according to three main forms: (i) Sprinkling [19,20], (ii) rural, and (iii) urban or suburban sprawl [21]. Romano et al. define 'sprinkling' as "[land] take with a partially spontaneous development, or subject to low controls, adding on to a historical structure. The built-up areas are not homogeneous in size and use, with a mixture of rural, residential, $[\ldots]$ functions [ ... ]" [19] (p. 4). Sprinkling is quite common in Italy, but also in southern Europe [19]. Rural sprawl refers to housing expansion far from urban settlements [21]. According to the Encyclopaedia Britannica, urban or suburban sprawl means "the rapid expansion of the geographic extent of cities and towns, often characterized by low-density residential housing, single-use zoning, and increased reliance on the private automobile for transportation" [22].

Rural sprawl and sprinkling play a non-marginal role in increasing habitat loss and triggering LF processes $[19,21,23]$. Metrics specifically proposed to quantify LF caused by rural buildings are scarcely discussed in scientific literature. Then, this research focuses on the influence of the built-up rural dimension on LF in areas protected by N2000 network, given its relevance for habitats and species protection and conservation. The idea is that LF assessment is key to addressing suitable policies, with respect to ecosystem preservation and ideal functioning. Starting from [24] we aim at measuring the dynamics of LF in six landscape units (LUs) set by the Regional Landscape Plan (RLP) of Sardinia (Italy) [25] by applying two indices: The rural buildings fragmentation index (RBFI, see [26] and the effective mesh density (Seff) [1]. In addition, we apply the average nearest neighbor (ANN) approach $[27,28]$ to investigate on the interplay between built-up spatial pattern and LF. In detail, we aim at answering two research questions (RQs). $R Q_{1}$ concerns the measure of $L F$ due to rural buildings in N2000 sites by using the RBFI, while $R_{2}$ regards the correlation between $R B F I$ and Seff. $R Q_{1}$ allows us to figure out if and to what extent the RBFI is affordable in measuring LF. In this vein, we apply the RBFI in a rural context interested by N2000 sites. We would expect to find low levels of LF in these areas, since the N2000 network should promote habitat and species conservation. $R_{2}$ focuses on the RBFI and its correlation with the Seff, which is a well-known metric. We aim at understanding if the RBFI confirms, integrates, or negates the findings we can obtain by applying the Seff.

In the next section, we report on the scientific literature concerning LF and habitat loss due to rural buildings and LF in N2000 sites, illustrate metrics, data and software used, and describe the study areas. In the third and fourth sections, we show and-respectively-discuss the findings. Finally, in the fifth section we report on the concluding remarks.

\section{Materials and Methods}

In this section, we reported on the main scientific studies concerning LF in N2000 sites and habitat loss caused by rural buildings, metrics and data and software used, and the characteristics of the study areas.

\subsection{Literature Review Summary}

Human infrastructures and settlements are key factors in LF [5,6] and affect protected areas and biodiversity [2]. Some scholars stress that further research is needed to investigate deeply "fragmentation at landscape scales" [29] (p. 272). 
LF in N2000 sites has attracted the interest of international scholars. Hernando et al. [30] measured LF in Spain through a morphological spatial pattern analysis and report on the importance of the forest cover map resolution for assessing habitat conservation status. The authors stress that: (i) The resolution of input cover maps affects the findings of morphological spatial pattern analysis and (ii) the appraisal of habitat conservation depends on the spatial resolution of cover maps [30]. Piquer-Rodríguez et al. [31] consider land-use change as a factor affecting connectivity of protected areas and focus on the province of Almería, Andalusia, in southeastern Spain. The authors proposed and applied a method consisting of the integration of spatially land-use models with LF analyses "in order to assess the effects of future land use on the connectivity of current protected area networks" [31] (p. 327). The morphological spatial pattern analysis was used to measure LF. The authors stated that conservation planning should consider the future land use orientation, because it has relevant relations with connectivity and resilience. Tomaselli et al. [32] apply several LF metrics in three coastal wetlands included in N2000 sites instituted in Apulia (Italy). The authors used the well-known software FRAGSTATS [33] to process LF metrics and "investigate [the reliability of the metrics] in assessing fragmentation and spatial patterns of habitats" [32] (p. 693).

Most of the times, N2000 sites are localized in rural areas, where TMIs and rural settlement contribute to LF and, thus, loss of natural and semi-natural habitats. In this study, we considered the rural sprawl as a factor that contributes in increasing habitat loss and LF. Suburban sprawl is characterized by higher housing density (housing units $/ \mathrm{km}^{2}$ ) than the rural sprawl [34]. The latter one affects "much larger areas than suburban sprawl" [34] (p. 794) since it exerts on each house remarkable and harmful environmental effects that take place in less altered contexts [34]. According to Hansen et al. [35] (p. 1893), "many native species have reduced survival and reproduction near homes" in low-density rural home settlement (from 6 to 25 houses $/ \mathrm{km}^{2}$ ). According to Theobald et al. [36], the area covered by rural buildings and their surrounding degraded habitat is definable as 'disturbance zone'. This concept mirrors the idea that habitat quality is affected (i.e., mostly depleted) not only in the area covered by human development (i.e., roads, houses, etc.), but also beyond a certain distance [37]. Finally, the ecological effect of rural buildings in the form of habitat loss has been proved by previous other studies [21,34,38]. At a given housing density, dispersed buildings show a most significant role, in terms of habitat fragmentation increase [21,36], although some studies found out that "clustering of buildings (expansion) in the rural landscape has the same impact on habitats as scattered building (generation)" [38] (p. 267). Over time, metrics able to measure LF due to the built-up rural dimension have been proposed and included "proportion of undisturbed area, decrease in largest patch area, decrease in median patch area, and change in total edge" [21] (p. 221). In 2017, De Montis et al. [26] proposed and applied the RBFI as metric for measuring LF caused by rural buildings in Sardinia. In the light of the foregoing studies, in this paper we aimed at answering the RQs introduced in Section 1.

\subsection{Landscape Fragmentation Metrics}

Sardinian rural landscapes are often characterized by isolated buildings or small clusters of rural buildings such as in the historical regions of Gallura and Nurra, in Northern Sardinia [39]. Thus, in this work we focused on LF caused by rural buildings and applied the RBFI [26], an index obtained by modifying the urban fragmentation index (UFI) [40]:

$$
\mathrm{UFI}=\frac{\sum_{\mathrm{i}=1}^{\mathrm{i}=\mathrm{n}} S_{i}}{A} \cdot \frac{\sum_{\mathrm{i}=1}^{\mathrm{i}=\mathrm{n}} P_{i}}{2 \sqrt{\pi \sum_{\mathrm{i}=1}^{\mathrm{i}=\mathrm{n}} S_{i}}}
$$

where $A$ stands for reference surface area (LU, N2000 site, and so on), and $S_{i}$ and $P_{i}$ for the area and perimeter of the surface occupied by urbanized areas. 
The RBFI obeys the following Equation (2):

$$
\text { RBFI }=N^{*} \cdot \frac{\sum_{\mathrm{i}=1}^{\mathrm{i}=\mathrm{n}} S_{i}^{*}}{A^{2}} \cdot \frac{\sum_{\mathrm{i}=1}^{\mathrm{i}=\mathrm{n}} P_{i}^{*}}{2 \sqrt{\pi \sum_{\mathrm{i}=1}^{\mathrm{i}=\mathrm{n}} S_{i}^{*}}},
$$

where $N^{*}$ stands for number of areas (urban nucleus) occupied by rural buildings included in a N2000 site, $A$ for surface area of the N2000 site, and $S_{i}{ }^{*}$ and $P_{i}{ }^{*}$ for area and perimeter of the surface occupied by rural buildings. The RBFI integrates the urban dispersion (URD), an index able to measure the distribution of urban nucleus [41]. The URD is conceived as a superficial density of urban settlements and obeys to the following Equation (3):

$$
\mathrm{URD}=\frac{N}{A}
$$

where $N$ stands for the number of urban nucleus centroids and $A$ for the reference area. Furthermore, we are interested in assessing the correlation between RBFI and other well-known metrics able to measure LF. The effective mesh size $\left(\mathrm{m}_{\mathrm{eff}}\right)$ is a well-tested index (see, inter alia: $\left.[1,42]\right)$ and it "is based on the probability that two randomly located points [ ... ] in an area [or in the same patch] are connected, [i.e., they] are not separated by a barrier" [43] (p. 39). However, in this study we considered the Seff because it is more suitable than $\mathrm{m}_{\mathrm{eff}}$ for monitor changes in trends $[1,42]$. The Seff provides us with the effective number of meshes per square kilometer. According to the EEA [1] (p. 24), it "is often more convenient to count the effective number of meshes per $1000 \mathrm{~km}^{2}$ rather than per $1 \mathrm{~km}^{2 \prime}$. Thus, we expressed the values of Seff in meshes (or landscape patches) per $1000 \mathrm{~km}^{2}$. When the LF increases the Seff increases as well [1,43]. The Seff obeys the following Equation (4) [1]:

$$
\mathrm{S}_{\mathrm{eff}}=\frac{1}{\mathrm{~m}_{\mathrm{eff}}}
$$

where $\mathrm{m}_{\text {eff }}$ obeys the following Equation (5):

$$
\mathrm{m}_{\mathrm{eff}}=\frac{1}{A_{t}} \times \sum_{i=1}^{n} A_{i}^{2}
$$

where $n$ stands for number of patches, $A_{i}$ for surface area of $n$ patches and $A_{t}$ for extent of the N2000 site. The Seff considers buildings and TMIs.

We measured RBFI and Seff and their variation according to the following Equations (6)-(9):

$$
\begin{aligned}
\Delta \mathrm{RBFI} & =\mathrm{RBFI}_{2008}-\mathrm{RBFI}_{2003} . \\
\mathrm{dRBFI} & =\frac{\mathrm{RBFI}_{2008}-\mathrm{RBFI}_{2003}}{\mathrm{RBFI}_{2003}} . \\
\Delta \text { Seff } & =\operatorname{Seff}_{2008}-\operatorname{Seff}_{2003} . \\
\mathrm{d} \text { Seff } & =\frac{\operatorname{Seff} f_{2008}-\operatorname{Seff}_{2003}}{\operatorname{Seff} f_{2003}} .
\end{aligned}
$$

Finally, we investigated the relation between the built-up spatial pattern and type of LF, by applying the ANN approach. In other words, we considered the reciprocal location and distance among rural buildings (centroids), which characterized the clustered, random, or dispersed built-up pattern. At a given building density (expressed in number of buildings per square kilometer), different built-up spatial patterns may imply different effects on ecosystems and biodiversity. The ANN "[c]alculates a nearest neighbor index based on the average distance from each feature to its nearest neighboring feature" [44]. The ANN allowed us to calculate five values concerning: "Observed Mean Distance [OMD], Expected Mean Distance [EMD], Nearest Neighbor Index [Nearest Neighbor Ratio], z-score, and $p$-value" [44]. The ANN has been adopted in other studies concerning LF and habitat 
conservation: For example, in [45] ANN distance between woodlots was calculated for assessing the "capacity of trees to move [considering the seed dispersal distances of the major tree species] between landscape patches" [45] (p. 332).

According to [46], the nearest neighbor ratio (NNR) is obtained as the ratio between OMD (Observed Mean Distance) and EMD and obeys to the following Equation (10):

$$
\mathrm{NNR}=\frac{\mathrm{OMD}}{\mathrm{EMD}}
$$

When NNR is greater than 1, the spatial pattern can be resembled to a dispersed type. Values of NNR smaller than 1 indicate a clustered spatial pattern.

\subsection{Data and Software}

The autonomous region of Sardinia approved the RLP in 2006 [25]. The RLP aims at preserving, protecting, and enhancing the environmental, historical, cultural, and settlement identity of Sardinia. Furthermore, the plan aims at protecting natural landscape and biodiversity, promoting forms of sustainable development. According to the RLP, 27 coastal LUs were instituted. During the 2010s, the autonomous region of Sardinia-also in collaboration with the two regional universities of Cagliari and Sassari-launched the update of the RLP with the aim at extending its domain over the remaining 24 inland LUs. In this study, we selected six LUs of approximately the same extent out of the 51 coastal and inland LUs.

As a source of data concerning LUs and built-up rural dimension (buildings and TMIs), we used the 1:25,000 Corine Land Cover based-land use maps for the years 2003 and 2008 in shapefiles format. These dataset are available on-line through the official website of the autonomous region of Sardinia [47]. The 2003 land use map was implemented by using the 1997 National Body for Interventions on the Agricultural Market (in Italian, Azienda di Stato per gli interventi sul mercato agricolo) orthophotos, 1:10,000 regional technical map, 1997-1998 LandSat images, further information and site surveys. The minimum mapped unit area was 1 hectare in urban areas and 1.5 hectares in rural areas. The 2008 land use map was rooted in the one released in 2003. It was updated by using the 2003 Italian Agricultural Payments Agency (in Italian, Agenzia per le Erogazioni in Agricoltura) orthophotos, orthophotos released in 2004, 2005-2006 Ikonos images, 2003 Landsat images, 2004 Aster images and further data. The minimum mapped unit area was 0.5 hectares in urban areas and 0.75 hectares in rural areas.

We stressed that the regional land use map covered rural buildings including their unbuilt surrounding area. Then, the surface area occupied by the rural buildings could often be overestimated. More accurate data would have been desirable but at the time of the study such data were not freely available. On the other hand, the excess of surface surrounding the rural buildings could be considered as a sort of disturbance zone, given that it concerns qualitatively degraded or compromised spaces and, usually, it consisted of a buffer of a few meters around the buildings. In other words, such a disturbance zone could not longer be recognized as a natural and semi-natural habitat, but it was a surface area ecologically depleted by human action (Figure 1). As shown in Figure 1, in some cases the built-up area consisted of more than one rural building.

The characterization of N2000 sites was based on a combination of different sources: (i) Regional data [47], (ii) the 1:50,000 map of the nature system released by the Italian Institute for Environmental Protection and Research [48], and (iii) information available from the European Environment Agency [49]. The map of the nature system includes information concerning biotopes, such as type, surface area, and ecological value.

The shapefiles were processed by using ESRI ArcGIS 10 [50], QGIS 3.2 [51], and Microsoft Excel 2010 [52]. We also used the ANN tool provided by ESRI ArcMAP 10 in order to investigate the built-up spatial pattern of rural buildings in the most fragmented N2000 sites. 


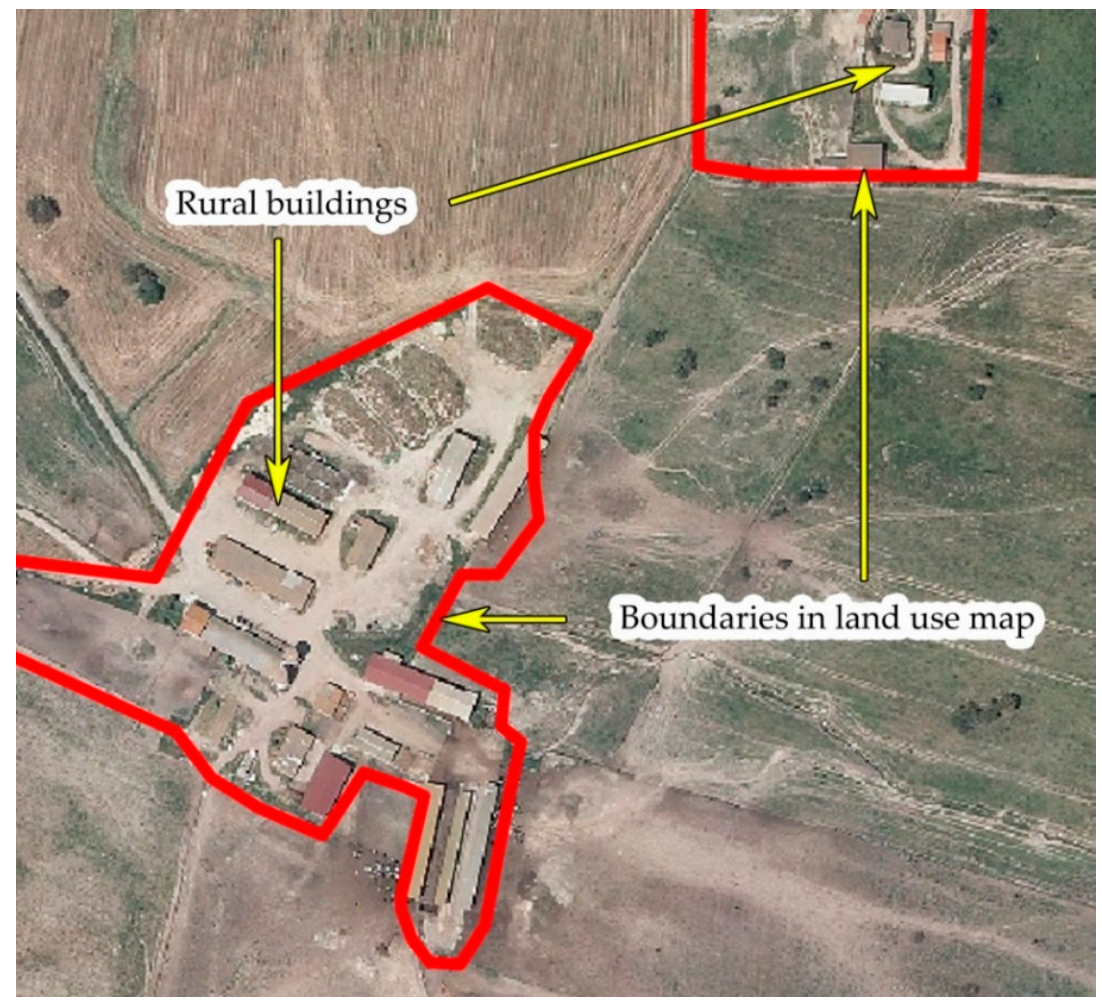

Figure 1. Example of representation offered by the regional land use map: The red boundary line includes an area that comprehends both rural buildings and their unbuilt surrounding areas.

\subsection{Study Areas}

The European Union has the following N2000 biogeographical regions [53]: Atlantic, Boreal, Continental, Alpine, Pannonian, Steppic, Black Sea, Mediterranean, and Macaronesian [54]. The Mediterranean biogeographical region includes-totally or partially-Cyprus, France, Greece, Italy, Malta, Portugal, and Spain [54]. The entire island of Sardinia belongs to such biogeographical region [55]. The Mediterranean region is characterized by high rate of endemism, as it hosts almost a half of the species included in the Habitats Directive [54]. Furthermore, the Mediterranean region is home for "more plant species [ ... ] than all the other European biogeographical regions combined [and for the] majority of Europe's reptiles" [54]. Scholars stress that endemic species have significant conservation priority (see, inter alia, [56]), and several of them live in islands. The Tyrrhenian islands-to which Sardinia belongs-are considered key "hotspots of endemism within Europe" [56]. However, the Mediterranean region is affected by tremendous human pressure especially in coastal areas because of tourism activities, while the inland areas are being abandoned [54]. Considered the impact of human actions and infrastructure, the N2000 network can contribute in protect habitats and species.

We focused on N2000 sites in Sardinia, because this region included many of them and LF might negatively affect such areas of particular ecological value. LF caused by TMIs has been recently considered in the map of the nature system of Sardinia, where the anthropic pressure has been assessed [55] and provides an assessment of human disturbance on habitat Corine biotopes. Furthermore, LF of Sardinian landscapes appears significant when compared to LF in other European regions as reported in a recent study on LF in Sardinia and Andalusia (Spain) [3,57]. De Montis et al. [3] point out that both the south-European regions show similar geographical and landscape features, as well as a similar institutional contexts. In both regions, LF showed remarkable relevance in coastal areas. However, such a recent study did not focus on LF due to rural buildings, while as reported in Section 2.1 the built-up rural areas could have a significant effect on rural landscapes in terms of soil consumption, habitat degradation, and loss of biodiversity. Then, we had chosen the Sardinian rural 
landscapes dimension as the subject of our investigation, with a specific focus on N2000 sites given their relevance for biodiversity.

We identified six LUs of approximately the same extent, which included N2000 sites (Figure 2). In Appendix A, Table A1 reports on type of N2000 sites, a partial list of protected species and habitats, and availability of the management plan of SAC, SCI, and SPA. The management plan plays a key role for pursuing conservation objectives, as it is site-specific, i.e., it is designed for and tailored on a specific N2000 site. The management plans aim at identifying (i) conservation measures that need to be implemented to satisfactorily maintain or restore natural habitat types and habitats for species of community interest, and (ii) measures that can be financed [58].
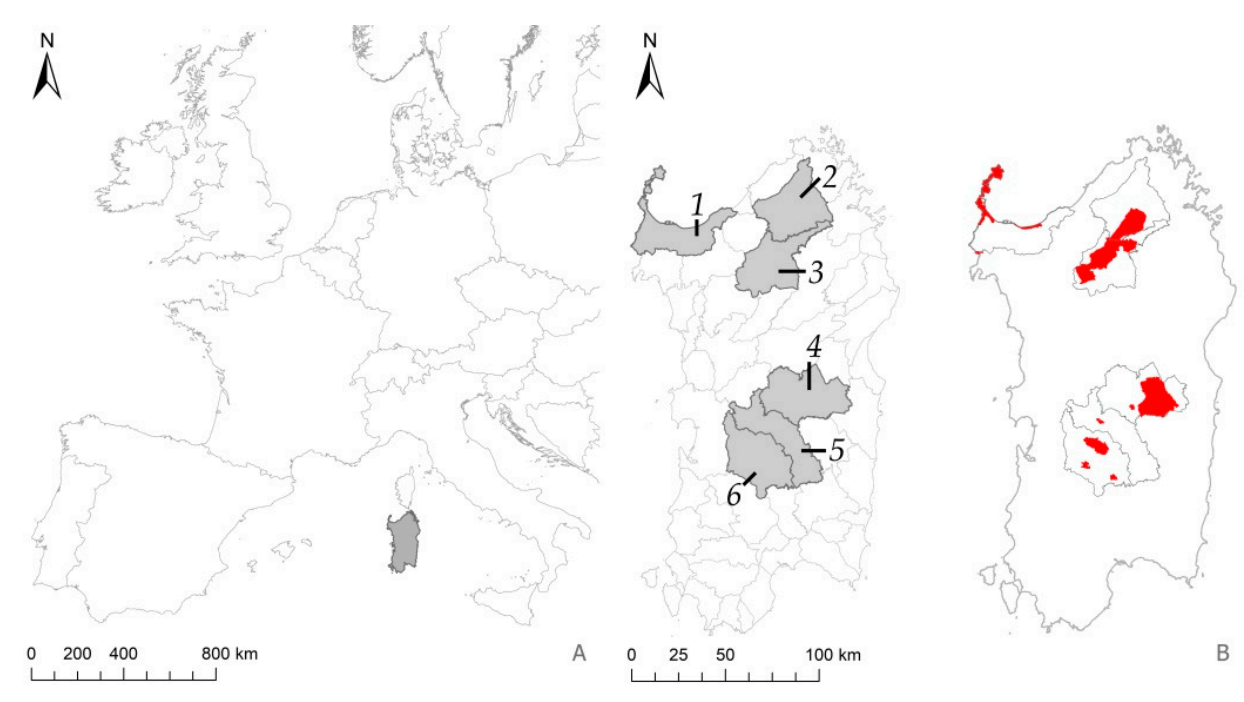

Figure 2. Geographic context. (A) In gray, the region of Sardinia. (B) In gray, the landscape units (LUs); in red, the Natura 2000 sites included within the LUs.

Table 1 reports on relevant characteristics for understanding general phenomena interesting the LUs: In the fourth column, the percentage of LU's surface area included in N2000 sites and, in the sixth and eighth column, the percentage of N2000 sites' surface area covered by houses in 2003 and 2008. Figures show that the N2000 sites extend over a significant surface area in Piana del Riu Mannu di Ozieri (30.84\%) and Gennargentu and Mandrolisai (29.13\%), and over a negligible area in Flumendosa-Sarcidano-Araxisi (0.6\%). Piana del Riu Mannu di Ozieri shows the highest absolute values of built-up area $\left(1.86 \mathrm{~km}^{2}\right.$ in 2003 and $2.71 \mathrm{~km}^{2}$ in 2008). This LU shows also the highest percentage of N2000 sites surface area covered by houses (0.69\% in 2003 and $1.01 \%$ in 2008). Regione delle Giare Basaltiche was devoid of rural buildings in 2003, and Flumendosa-Sarcidano-Araxisi does not show any rural buildings in 2003 and 2008.

Table 1. Details about the N2000 sites within the LUs.

\begin{tabular}{|c|c|c|c|c|c|c|c|}
\hline LUs & $\begin{array}{l}\text { (A) Area } \\
\text { LU }\left(\mathrm{km}^{2}\right)\end{array}$ & $\begin{array}{l}\text { (B) Area } \\
\text { N2000 Sites } \\
\text { within the } \\
\text { LU }\left(\mathrm{km}^{2}\right)\end{array}$ & $\begin{array}{l}\text { Ratio } \\
\text { (B)/(A) }\end{array}$ & $\begin{array}{c}\text { (C) N2000 } \\
\text { Sites } \\
\text { Built-Up } \\
\text { Rural Area } \\
\left(\mathrm{km}^{2}\right)\end{array}$ & $\begin{array}{l}\text { Ratio } \\
\text { (C)/(B) }\end{array}$ & $\begin{array}{c}\text { (D) N2000 } \\
\text { Sites } \\
\text { Built-Up } \\
\text { Rural Area } \\
\left(\mathrm{km}^{2}\right)\end{array}$ & $\begin{array}{l}\text { Ratio } \\
\text { (D)/(B) }\end{array}$ \\
\hline & & & & \multicolumn{2}{|c|}{2003} & \multicolumn{2}{|c|}{2008} \\
\hline (1) Golfo dell'Asinara & 807.13 & 90.00 & $11.15 \%$ & 0.07 & $0.08 \%$ & 0.17 & $0.19 \%$ \\
\hline (2) Massiccio del Limbara & 924.00 & 166.24 & $17.99 \%$ & 0.25 & $0.15 \%$ & 0.27 & $0.16 \%$ \\
\hline (3) Piana del Riu Mannu di Ozieri & 870.48 & 268.44 & $30.84 \%$ & 1.86 & $0.69 \%$ & 2.71 & $1.01 \%$ \\
\hline (4) Gennargentu and Mandrolisai & 1010.22 & 294.25 & $29.13 \%$ & 0.10 & $0.03 \%$ & 0.11 & $0.04 \%$ \\
\hline (5) Flumendosa-Sarcidano-Araxisi & 820.79 & 4.93 & $0.60 \%$ & - & - & - & - \\
\hline (6) Regione delle Giare Basaltiche & 926.09 & 80.01 & $8.64 \%$ & - & - & 0.02 & $0.02 \%$ \\
\hline
\end{tabular}




\section{Results}

Table 2 reports on the results of this paper. The highest values of RBFI (about $0.043 \mathrm{~km}^{-2}$ in 2003 and $0.132 \mathrm{~km}^{-2}$ in 2008) were measured in N2000 sites of Piana del Riu Mannu di Ozieri, while the rural buildings did not contribute to LF in N2000 sites in Flumendosa-Sarcidano-Araxisi. N2000 sites in Gennargentu and Mandrolisai showed the lowest RBFI $\left(0.000017 \mathrm{~km}^{-2}\right)$ in 2003, while Regione delle Giare Basaltiche the lowest one (0.000013) in 2008. Piana del Riu Mannu di Ozieri had the highest difference ( $\triangle \mathrm{RBFI})$ of RBFI from 2003 to $2008\left(0.089035 \mathrm{~km}^{-2}\right)$. Golfo dell'Asinara and Piana del Riu Mannu di Ozieri showed a remarkable increase (dRBFI) of RBFI from 2003 to 2008 (1271\% and 204.1\%, respectively), while Gennargentu and Mandrolisai had the lowest one (32.9\%).

Table 2. Values of rural buildings fragmentation index (RBFI) and the effective mesh density (Seff) and their variation from 2003 to 2008.

\begin{tabular}{|c|c|c|c|c|c|c|c|c|}
\hline \multirow[t]{2}{*}{ Natura 2000 Sites in LU } & \multicolumn{2}{|c|}{ RBFI $\left(\mathbf{k m}^{-2}\right)$} & \multirow[t]{2}{*}{$\begin{array}{c}\Delta \mathrm{RBFI}_{03-08} \\
\left(\mathrm{~km}^{-2}\right)\end{array}$} & \multirow[t]{2}{*}{$\mathrm{dRBFI}_{03-08}$} & \multicolumn{2}{|c|}{$\begin{array}{l}\text { Seff (meshes per } \\
1000 \mathrm{~km}^{2} \text { ) }\end{array}$} & \multirow[t]{2}{*}{$\Delta$ Seff $_{03-08}$} & \multirow[t]{2}{*}{ dSeff $_{03-08}$} \\
\hline & 2003 & 2008 & & & 2003 & 2008 & & \\
\hline (1) Golfo dell'Asinara & 0.000076 & 0.001036 & 0.000960 & $1271.0 \%$ & 26.653406 & 26.886335 & 0.232928 & $0.9 \%$ \\
\hline (2) Massiccio del Limbara & 0.000750 & 0.001059 & 0.000309 & $41.2 \%$ & 6.088005 & 6.091561 & 0.003556 & $0.1 \%$ \\
\hline (3) Piana del Riu Mannu di Ozieri & 0.043633 & 0.132668 & 0.089035 & $204.1 \%$ & 3.843349 & 3.894713 & 0.051364 & $1.3 \%$ \\
\hline (4) Gennargentu and Mandrolisai & 0.000017 & 0.000023 & 0.000006 & $32.9 \%$ & 3.531986 & 3.531656 & -0.000331 & $0.0 \%$ \\
\hline (5) Flumendosa-arcidano-Araxisi & - & - & - & - & - & - & - & - \\
\hline (6) Regione delle Giare Basaltiche & - & 0.000013 & - & - & 19.056070 & 19.059484 & 0.003415 & $0.0 \%$ \\
\hline
\end{tabular}

N2000 sites in Golfo dell'Asinara and Regione delle Giare Basaltiche showed the highest values of Seff (respectively, around 26 and 19 meshes per $1000 \mathrm{~km}^{2}$ ), while Gennargentu and Mandrolisai showed the lowest one (about 3.5). The variations of Seff were not significant from 2003 to 2008. According to the RBFI, N2000 sites in Piana del Riu Mannu di Ozieri appeared as the most fragmented, while according to the Seff the most fragmented N2000 sites were localized in Golfo dell'Asinara.

We assessed the relationship concerning dRBFI, dSeff, and the area occupied by N2000 sites within the LUs (Table 3) and found out that dRBFI and dSeff were weakly positively correlated (Pearson's correlation coefficient, PCC $=0.45$ ), while the dRBFI was negatively correlated to the areas covered by the N2000 sites (PCC $=-0.74$ ). We stressed that the PCC was calculated for the four LUs where the metrics had varied over time, then excluding Flumendosa-Sarcidano-Araxisi and Regione delle Giare Basaltiche.

Table 3. Correlation analysis of the metrics.

\begin{tabular}{ccccc}
\hline & & \multicolumn{2}{c}{ PCC } \\
\hline & & $\mathrm{dRBFI}_{03-08}$ & $\mathrm{dSeff}_{03-08}$ & Ratio area N2000 sites/area LU \\
\multirow{2}{*}{ PCC } & dRBFI $_{03-08}$ & - & 0.45 & -0.74 \\
& $\mathrm{dSeff}_{03-08}$ & 0.45 & - & 0.05 \\
& Ratio area N2000 sites/area LU & -0.74 & 0.05 & - \\
\hline
\end{tabular}

The highest RBFI was measured in the N2000 sites in LU Piana del Riu Mannu di Ozieri, where we calculated 0.4 buildings per square kilometer in 2003, while in 2008 the housing density was 0.7 buildings per square kilometer. Then, we focused on such N2000 sites and investigated the built-up spatial pattern of rural buildings in 2003 and 2008, by using the ANN tool. We converted the rural buildings in centroids and applied the ANN (Figures 3 and 4 and Table 4 ). Figures 3 and 4 report on the metrics introduced in Section 2.3: OMD, EMD, NNR, z-score, and $p$-value. The z-score ranged from less than -2.58 to more than 2.58 , while the $p$-value ranged from less than 0.01 to 0.1 . The lower is the $p$-value the more significant is the pattern. 


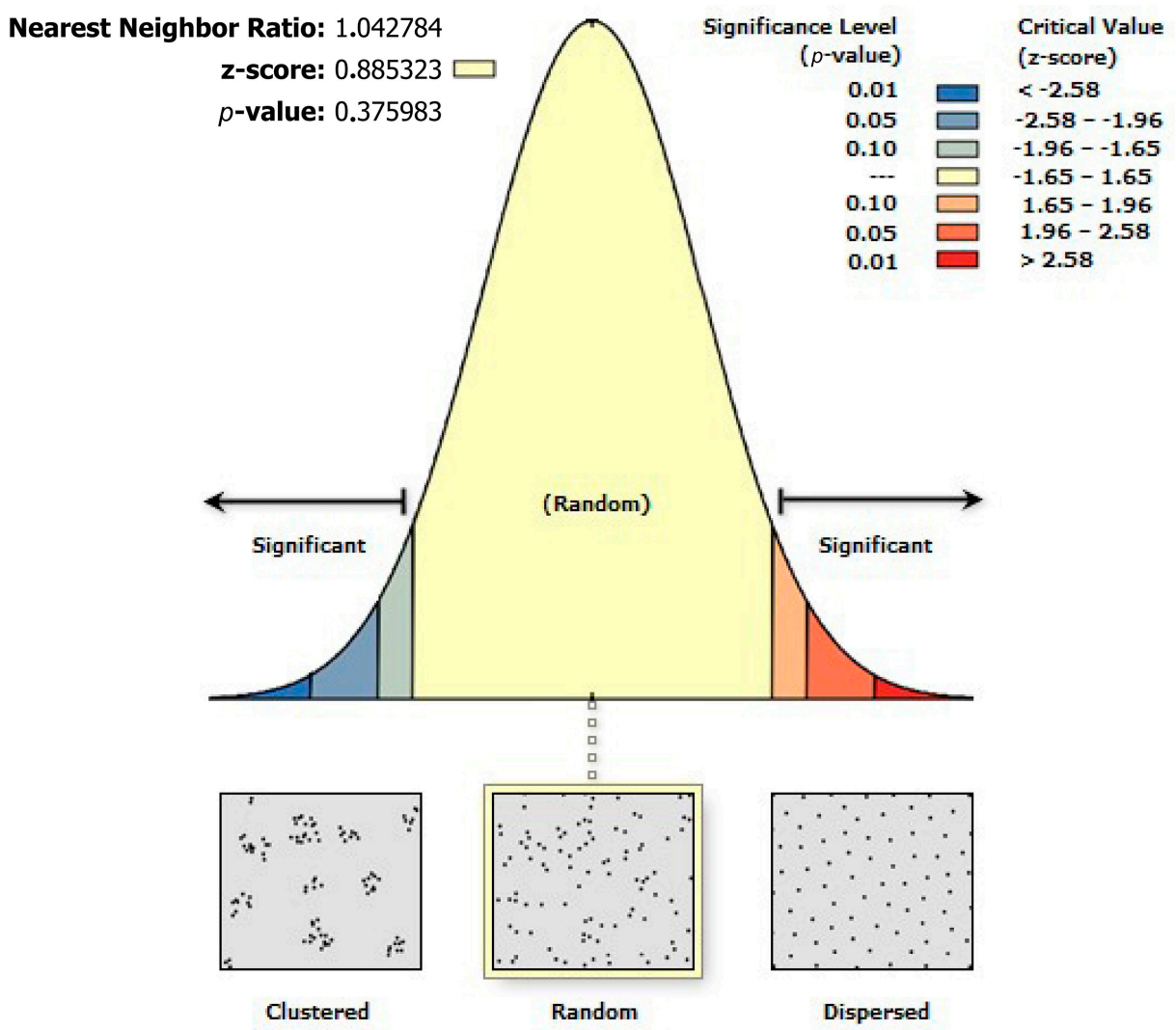

Figure 3. Random pattern. Given the z-score of 0.885322918131 , the pattern does not appear to be significantly different from random.

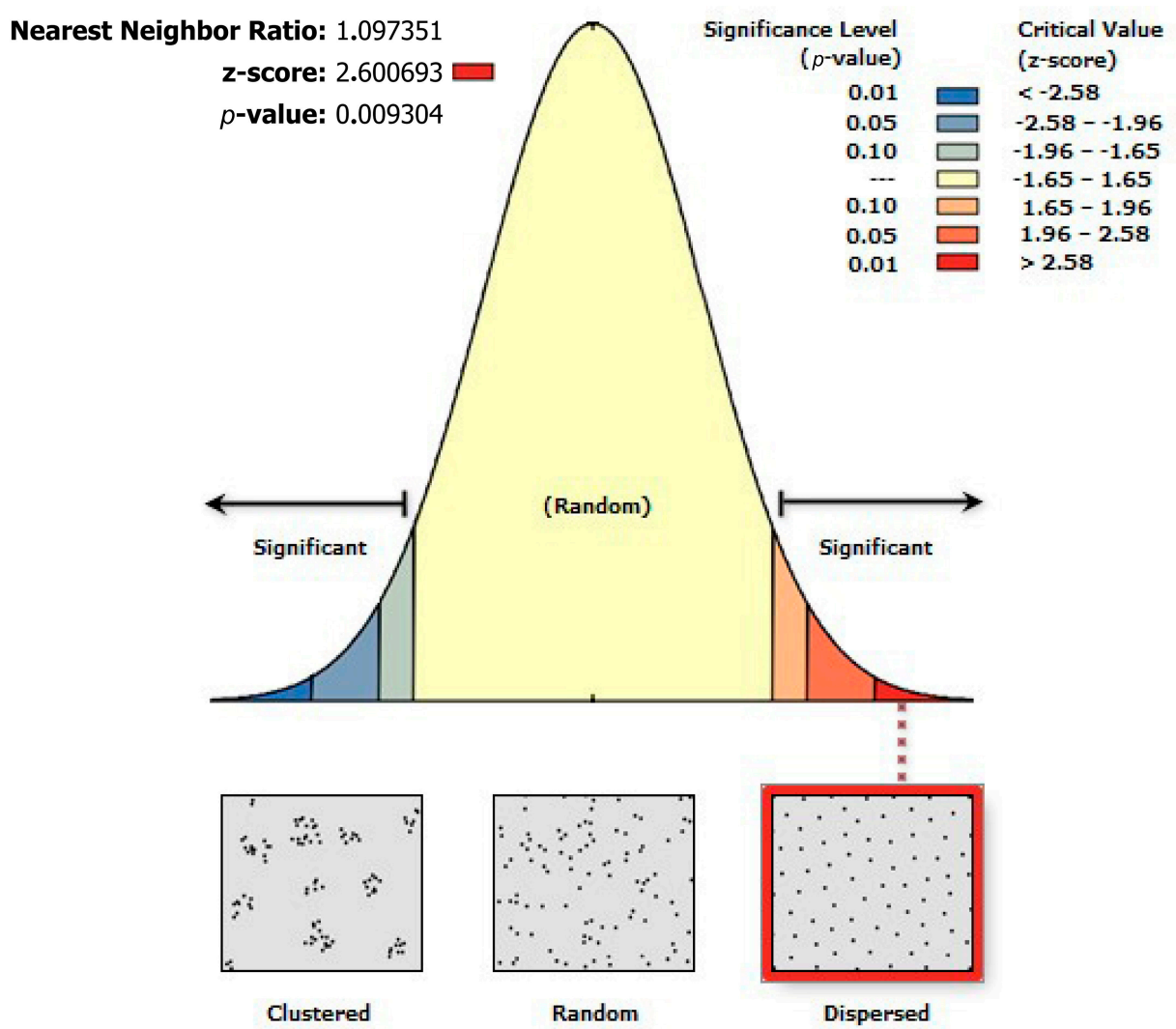

Figure 4. Dispersed pattern. Given the z-score of 2.60069282886 , there is a probability less than $1 \%$ that this dispersed pattern could be the result of random chance. 
Table 4. N2000 sites in Piana del Riu Mannu di Ozieri. Average nearest neighbor summary. Study area: About $268 \mathrm{~km}^{2}$.

\begin{tabular}{|c|c|c|c|}
\hline \multirow[t]{2}{*}{ Description } & \multicolumn{2}{|c|}{ Year } & \multirow[t]{2}{*}{$\Delta 08-03$} \\
\hline & 2003 & 2008 & \\
\hline Euclidean OMD (m) & 789.8 & 643.8 & -146.0 \\
\hline Euclidean EMD (m) & 757.4 & 586.7 & -170.7 \\
\hline NNR & 1.042 & 1.097 & 0.055 \\
\hline z-score & 0.885 & 2.600 & \\
\hline$p$-value & 0.375983 & 0.009304 & \\
\hline
\end{tabular}

As for 2003, Figure 3 suggests a random pattern according to the NNR of 1.042, the z-score of about 0.885 and $p$-value 0.375 . The z-score refers to the number of standard deviations of each value compared to the average. A z-score equal to zero corresponds to the mean of the original variable values. Thus, 0.885 was near to zero and then near the average value. As for 2008, Figure 4 suggests a dispersed pattern according to the NNR of 1.097, the z-score of about 2.600 and $p$-value 0.009 .

Table 4 reports on the ANN summary considering the surface area of the N2000 sites (about $268 \mathrm{~km}^{2}$ ) in Piana del Riu Mannu di Ozieri. From 2003 to 2008 the OMD decreased from $789.8 \mathrm{~m}$ to $643.8 \mathrm{~m}$, and the EMD decreased from $757.4 \mathrm{~m}$ to $586.7 \mathrm{~m}$. The highest housing density characterized this pattern and might imply a different type of LF compared with the one of the clustered patterns.

From 2003 to 2008 about $0.86 \mathrm{~km}^{2}$ of habitats were degraded by rural buildings, and the biotopes involved mainly consisted of subnitrophilous Mediterranean meadows $\left(-0.64 \mathrm{~km}^{2}\right)$, extensive crops and complex agricultural systems $\left(-0.12 \mathrm{~km}^{2}\right)$, and wooded pasture (Dehesa, $-0.03 \mathrm{~km}^{2}$ ).

As for the planning issues, we found out that the two N2000 sites in LU Piana del Riu Mannu di Ozieri were not regulated by management plans yet. However, the management plan of SPA 'Piana di Ozieri, Mores, Ardara, Tula e Oschiri' was currently under Strategic Environmental Assessment (SEA) procedure and could come into force once the procedure will be successful concluded. In fact, in Sardinia the management plans of N2000 sites must be subjected to an SEA screening procedure or directly to an SEA process depending on the criteria defined in the 'Guidelines for drawing up management plans of SCIs and SPAs' released in 2012 by the autonomous region of Sardinia [58].

\section{Discussion}

The interest of scholars in protection and conservation of biodiversity has increased over time. Currently, scientific research is still focusing on habitat and landscape fragmentation as causes affecting survival and dispersion of fauna and flora populations and the Habitat and Birds Directives are part of European strategies that aim at protecting biodiversity and natural habitats through the Natura 2000 network.

Effective protection strategies should be rooted in information describing the current habitat scenario of given regions. In other terms, data and information concerning availability of natural habitat, degree of habitat degradation, and factors that influence habitat quality should be known when protection and conservation measures have to be defined in a given context.

LF is one of the most important factors that have negative effects on habitat quality and population survival and dispersal. Such a phenomenon has been studied internationally by scholars. However, LF caused by rural buildings is still scarcely addressed by international scientific community. In this study we applied the RBFI, which specifically aimed at measuring LF due to the built-up rural dimension. We measured LF in N2000 sites falling within six LUs in Sardinia.

As a first consideration, in the most fragmented N2000 sites, we obtained a much lower housing density ( 0.4 houses $/ \mathrm{km}^{2}$ in 2003 and 0.7 houses $/ \mathrm{km}^{2}$ in 2008), with respect to the reference range (from 6 to 25 homes $/ \mathrm{km}^{2}$ ) associated by Hansen et al. [35] (p. 1893) to a negative effect on species survival and reproduction. Future research should investigate if the housing density influences the behavior of specific target species. The housing density measured in this study shows different values with respect 
to the ones characterizing the sprinkling $\left(0.1\right.$ houses/ha [19], or 10 houses $\left./ \mathrm{km}^{2}\right)$, even though it may be underestimated, since the regional land use maps of Sardinia is not accurate in the delimitation of rural buildings (see Section 2). Thus, we could not argue that the measured housing density could affect survival and reproduction of specific target species. On another side, we could argue that more precise and updated data should be used to ascertain the need of defragmentation measures, habitat restoration, and imposition of constraints to avoid soil (and habitat) consumption.

Secondly, as our main target was assessing LF due to rural buildings, we focused on LU Piana del Riu Mannu di Ozieri, where the most fragmented N2000 sites were localized, according to the RBFI. Thus, we investigated on the built-up spatial pattern characterizing rural buildings in 2003 and 2008. We obtained that the buildings in 2003 settled according to a random spatial pattern, while they were organized in a dispersed spatial pattern in 2008. Such patterns provided us with information about Euclidean OMD and Euclidean EMD and confirmed the intuitive reduction of both the distances from 2003 to 2008 due to the increase of the number of rural buildings over time. The dispersed spatial pattern suggests that rural development might follow some rules. We did not investigate on the reasons leading to a specific spatial pattern; more research is needed on this issue.

Thirdly, in the N2000 sites of LU Piana del Riu Mannu di Ozieri, we measured from 2003 to 2008 a diminution of surface area equal to $0.86 \mathrm{~km}^{2}$ and corresponding to degraded habitats caused by rural buildings. Such areas are mainly regarded as subnitrophilous Mediterranean meadows, extensive crops and complex agricultural systems, and wooded pasture (Dehesa). The N2000 sites were relevant to species, such as the little bustard (Tetrax tetrax) that lives in this area. The little bustard is a protected species [49] near threatened [59] and it is included in the management plan of SPA 'Piana di Ozieri, Mores, Ardara, Tula e Oschiri', which currently is subject to SEA [60] (see Table A1 in Appendix A). It would be desirable that the management plan considers the effect of rural buildings on specific target species such as the little bustard to plan proper conservation measures. Furthermore, the impact of TMIs should be considered by planners, in that roads and railways contribute in increasing LF and can affect animal movement and dispersion. In the light of the foregoing considerations, in our opinion the RBFI should also integrate the TMIs dimension to provide a more satisfying framework on habitat quality in N2000 sites.

Fourthly, the most fragmented-according to the RBFI-N2000 sites fall within the LU Piana del Riu Mannu di Ozieri, while the most fragmented-according to the values of Seff-N2000 sites fall within Golfo dell'Asinara and Regione delle Giare Basaltiche. Then, we obtained conflicting results. This could be explained by considering that the RBFI provides raw information on LF and, furthermore, it does not consider the network of TMIs, whose effect is encapsulated in the calculation of the Seff. Finer assessment of RBFI would require the integration of information connected to many more aspects and future research will investigate such an issue. Contrary to the RBFI, the values of Seff confirmed the results of previous studies (see, for example [3]), namely that the coastal areas often show a higher fragmentation with respect to the inland areas. However, the sample of areas analyzed needs to be enlarged to other contexts in future research to provide statistical evidence in the comparison between RBFI and Seff. In other words, the sample of areas scrutinized in this work was too limited to be considered statistically representative of certain phenomena.

\section{Conclusions}

Scientific literature has scarcely dealt with LF caused by rural buildings and proposed ad hoc metrics. Then, in this study we applied the so-called RBFI—a relatively new index-in a set of N2000 sites belonging to six LUs in Sardinia (Italy). Furthermore, we applied the Seff and assessed the variation of LF from 2003 to 2008. 
We aimed at answering to two RQs with the aim at contributing to the advancement of scientific research on the interplay between rural buildings and LF. $R Q_{1}$ concerned the application of RBFI for measuring LF in N2000 sites. The RBFI proved able to measure LF depending on the built-up rural dimension, as it provides quantitative responses to planners and politicians. On these bases, decision makers are better informed, when dealing with strategic choices and actions in the perspective of recovering degraded habitat, preserving wild fauna and flora, reconnecting rural areas, and restoring ecological corridors. Furthermore, in this study we considered the built-up spatial pattern of the most fragmented (according to the RBFI) N2000 sites. We used the ANN provided by ESRI ArcMAP 10 and found out that both Euclidean OMD and Euclidean EMD decreased from 2003 to 2008 and that the dispersed pattern characterized the built-up rural dimension in 2008. Then, we might assume that a remarkable surface area is affected by rural buildings. In other terms, if we consider the disturbance zone surrounding rural buildings, houses with the same surface area and perimeter exert different impacts, according to their spatial pattern [26]. When they are settled in a clustered pattern, they affect a smaller surface area with respect to the case where they are scattered in a dispersed pattern [26]. This could be relevant to specific target species, if we consider different disturbance zones corresponding to variable buffers around rural buildings. Such 'different disturbance buffers' may constitute degraded habitat or imply barrier effect phenomena for some species. Furthermore, more dispersed buildings imply more (and longer) roads and heavier vehicular traffic, elements that tend to increase LF and disturbance phenomena. However, we did not investigate 'if' and 'to what extent' the rural buildings affected flora and fauna. Then, we could not assess the effects of the dispersed pattern identified in the N2000 sites. Future research may investigate on such an issue on the ground.

In the current form, the RBFI shows weaknesses that should be dealt with in future research. Firstly, in this study we measured RBFI in surface areas of different extent. Then, the values of RBFI measured in the N2000 sites were not fully comparable with each other (similar issue stressed in [3]). Future studies should consider measuring RBFI by using a grid with predefined cell size, following other approaches [61]. In addition, a sensitivity analysis would be desirable to assess how RBFI varies, when its components vary (see, for example, [57]). Secondly, the metric may be improved by considering other factors, such as the effect of (i) TMIs (including, vehicle traffic and barrier effect), (ii) fencings surrounding farms, (iii) inhabited or uninhabited rural buildings, (iv) minimum habitat surface area for survival and dispersal of specific target species, and so on. One of the main issues regards the availability of data at the national, regional, and local level, which would be useful to perform more precise analysis.

As for the $\mathrm{RQ}_{2}$, we did not find trivial results: According to RBFI and Seff, different N2000 sites were assessed as the most fragmented. This could be explained by recalling that the RBFI does not consider the network of TMIs while the Seff does so. The RBFI could be improved by introducing additional information in future studies. The dRBFI appeared negatively correlated to the areas covered by the N2000 sites. We might interpret this outcome as a positive containing effect of the institution of a N2000 site in a given area: The larger the area included in N2000 sites, the lower the effect of buildings on LF. The increase of surface area occupied by rural settlement may be reduced or planned, according to an ecological point of view: In this sense, the institution of N2000 sites constitutes a strategic measure.

As a concluding remark, we stressed the importance of the exercise proposed in this paper for steering sustainability concerns that are of great interest for an international audience. Most of the times, landscape, and spatial planning tools are designed and evaluated with respect to their possible effects on the environment, according to the well-known SEA process [62]. SEA is applied also to the scrutiny of N2000 sites management plans. In these cases, a study on the effects of rural buildings on habitat and biodiversity may be integrated in the SEA report, given that SEA can contribute in considering biodiversity in spatial planning and promoting sustainable development [63]. In addition, a SEA of municipal master plans that considers the effect of rural sprawl may provide more information concerning the original scenario and present and future impacts on biodiversity. In this 
case, planners could define ad hoc alternatives, drawing up eco-sustainable plans able to reduce or contain rural sprawl (and negative effects on species). The effect of rural buildings on the environment could also be considered in management plans of N2000 sites per se, in order to analyze, inter alia, habitat fragmentation and compromised ecological corridors, according to [58], in the perspective of characterizing the areas where SCIs or SPAs are localized.

Author Contributions: Conceptualization: A.L., A.D.M. and V.S.; methodology: A.L. and A.D.M.; formal analysis: A.L. and V.S.; Writing-Original Draft preparation: A.L.; Writing-Review and Editing: A.D.M. and A.L.; supervision: A.D.M.

Funding: This research received no external funding.

Conflicts of Interest: The authors declare no conflict of interest.

\section{Appendix A}

Table A1 reports on the main features in the N2000 sites scrutinized in this study. 
Table A1. Characterization of the Natura 2000 sites.

\begin{tabular}{|c|c|c|c|c|c|}
\hline LUs & N2000 Sites [64] & $\begin{array}{l}\text { SAC, SCI, or SPA } \\
\text { Code [64] }\end{array}$ & $\begin{array}{l}\text { Partial Overview on Protected } \\
\text { Species (Full List: [49]) }\end{array}$ & $\begin{array}{l}\text { Partial Overview on Protected Habitats } \\
\text { (Full List: [49]) }\end{array}$ & $\begin{array}{l}\text { N2000 Sites (Code), } \\
\text { Management Plan(s) } \\
\text { (Yes or No), Year [64] }\end{array}$ \\
\hline (1) Golfo dell'Asinara & $\begin{array}{l}\text { SAC 'Stagno di Pilo e di Casaraccio'; } \\
\text { SAC 'Stagno e ginepreto di } \\
\text { Platamona'; SAC 'Lago di } \\
\text { Baratz-Porto Ferro'; SAC 'Coste e } \\
\text { Isolette a Nord Ovest della Sardegna'; } \\
\text { SAC 'Isola dell'Asinara'; SPA 'Isola } \\
\text { Asinara'; SPA 'Stagno di Pilo, } \\
\text { Casaraccio e Saline di Stintino'; SPA } \\
\text { 'Isola Piana di Porto Torres' }\end{array}$ & $\begin{array}{l}\text { SAC ITB010002, } \\
\text { ITB010003, } \\
\text { ITB011155, } \\
\text { ITB010043, } \\
\text { ITB010082; SPA } \\
\text { ITB010001, } \\
\text { ITB013012, } \\
\text { ITB013011 }\end{array}$ & $\begin{array}{l}\text { Discoglossus sardus (Tyrrhenian } \\
\text { painted frog), Aythya nyroca } \\
\text { (Ferruginous Duck), Rhinolophus } \\
\text { ferrumequinum (Greater horseshoe } \\
\text { bat), Caretta caretta (Loggerhead) }\end{array}$ & $\begin{array}{l}\text { Sandbanks, which are slightly covered by } \\
\text { sea water all the time, Posidonia beds } \\
\text { (Posidonion oceanicae), } \\
\text { Thermo-Mediterranean and pre-desert } \\
\text { scrub, Arborescent matorral with } \\
\text { Juniperus spp. }\end{array}$ & $\begin{array}{l}\text { SAC ITB010002, yes, 2008; } \\
\text { SAC ITB010003, yes, 2015; } \\
\text { SAC ITB011155, yes, 2015; } \\
\text { SAC ITB010043, yes, 2008; } \\
\text { SAC ITB010082, yes, 2016; } \\
\text { SPA ITB010001: Yes, 2016; } \\
\text { SPA ITB013012: No; SPA } \\
\text { ITB013011: Yes, } 2017\end{array}$ \\
\hline (2) Massiccio del Limbara & SCI 'Monte Limbara' & SCI ITB011109 & $\begin{array}{l}\text { Aquila chrysaetos (Golden Eagle), } \\
\text { Circus cyaneus (Hen Harrier), Falco } \\
\text { peregrinus (Peregrine), Testudo } \\
\text { marginata (Marginated tortoise) }\end{array}$ & $\begin{array}{l}\text { Pseudo-steppe with grasses and annuals of } \\
\text { the Thero-Brachypodietea, Quercus suber } \\
\text { forests, Quercus ilex and Quercus } \\
\text { rotundifolia forests, Mediterranean pine } \\
\text { forests with endemic Mesogean pines }\end{array}$ & No \\
\hline (3) Piana del Riu Mannu di Ozieri & $\begin{array}{c}\text { SCI ‘Campo di Ozieri e Pianure } \\
\text { Comprese tra Tula e Oschiri'; SPA } \\
\text { 'Piana di Ozieri, Mores, Ardara, Tula } \\
\text { e Oschiri' }\end{array}$ & $\begin{array}{l}\text { SCI ITB011113, } \\
\text { SPA ITB013048 }\end{array}$ & $\begin{array}{c}\text { Discoglossus sardus (Tyrrhenian } \\
\text { painted frog), Alcedo atthis } \\
\text { (Kingfisher), Ardea purpurea (Purple } \\
\text { Heron), Papilio hospiton (Corsican } \\
\text { Swallowtail), Tetrax tetrax (Little } \\
\text { Bustard) } \\
\end{array}$ & $\begin{array}{l}\text { Endemic phryganas of the } \\
\text { Euphorbio-Verbascion, Pseudo-steppe } \\
\text { with grasses and annuals of the Quercus ilex } \\
\text { and Quercus rotundifolia forests, Quercus } \\
\text { suber forests, Olea and Ceratonia forests }\end{array}$ & $\begin{array}{l}\text { SCI: No; SPA: Under } \\
\text { assessment }\end{array}$ \\
\hline (4) Gennargentu and Mandrolisai & $\begin{array}{l}\text { SAC 'Su de Maccioni-Texile di } \\
\text { Aritzo'; SCI and SPA 'Monti del } \\
\text { Gennargentu' }\end{array}$ & $\begin{array}{l}\text { SAC ITB022217, } \\
\text { SCI and SPA } \\
\text { ITB021103 }\end{array}$ & $\begin{array}{c}\text { Aquila chrysaetos (Golden Eagle), } \\
\text { Cervus elaphus corsicanus (Corsican } \\
\text { Red Deer), Myotis capaccinii } \\
\text { (Long-fingered bat), Rhinolophus } \\
\text { mehelyi (Mehely's horseshoe bat), } \\
\text { Euleptes europaea (European } \\
\text { leaf-toed gecko) }\end{array}$ & $\begin{array}{l}\text { Quercus ilex and Quercus rotundifolia forests, } \\
\text { Endemic phryganas of the } \\
\text { Euphorbio-Verbascion, Alpine and Boreal } \\
\text { heaths, Thermo-Mediterranean and } \\
\text { pre-desert scrub }\end{array}$ & $\begin{array}{l}\text { SAC: Yes, 2008; SPA: } \\
\text { Under assessment; SCI: } \\
\text { No }\end{array}$ \\
\hline (5) Flumendosa-Sarcidano-Araxisi & SCI 'Castello di Medusa' & SCI ITB032240 & $\begin{array}{c}\text { Speleomantes imperialis (Imperial } \\
\text { cave salamander), Accipiter gentilis } \\
\text { arrigonii (Goshawk, } \\
\text { (Corsican-Sardinian subspecies), } \\
\text { Anthus campestris (Tawny Pipit) }\end{array}$ & $\begin{array}{l}\text { Olea and Ceratonia forests, Quercus ilex and } \\
\text { Quercus rotundifolia forests, Quercus suber } \\
\text { forests, Salix alba and Populus alba galleries }\end{array}$ & No \\
\hline (6) Regione delle Giare Basaltiche & $\begin{array}{l}\text { SCI ‘Giara di Gesturi'; SAC 'Monte } \\
\text { San Mauro'; SPA 'Giara di Siddi' }\end{array}$ & $\begin{array}{l}\text { SCI ITB041112, } \\
\text { SAC ITB042237, } \\
\text { SPA ITB043056 }\end{array}$ & $\begin{array}{l}\text { Alectoris barbara (Barbary } \\
\text { Partridge), Ciconia ciconia (White } \\
\text { Stork), Lullula arborea (Woodlark), } \\
\text { Pluvialis apricaria (Golden Plover) }\end{array}$ & $\begin{array}{l}\text { Quercus suber forests, Quercus ilex and } \\
\text { Quercus rotundifolia forests, Pseudo-steppe } \\
\text { with grasses and annuals of the } \\
\text { Thero-Brachypodietea, Dehesas with } \\
\text { evergreen Quercus spp. }\end{array}$ & $\begin{array}{l}\text { SCI: Yes, 2017; SAC: Yes, } \\
\text { 2015; SPA: Yes, } 2016\end{array}$ \\
\hline
\end{tabular}




\section{References}

1. EEA. Landscape Fragmentation in Europe; European Environment Agency: Copenhagen, Denmark, 2011.

2. Harrisson, K.A.; Pavlova, A.; Amos, J.N.; Takeuchi, N.; Lill, A.; Radford, J.Q.; Sunnucks, P. Fine-scale effects of habitat loss and fragmentation despite large-scale gene flow for some regionally declining woodland bird species. Landsc. Ecol. 2012, 27, 813-827. [CrossRef]

3. De Montis, A.; Martín, B.; Ortega, E.; Ledda, A.; Serra, V. Landscape fragmentation in Mediterranean Europe: A comparative approach. Land Use Policy 2017, 64, 83-94. [CrossRef]

4. De Montis, A.; Ledda, A.; Ortega, E.; Martín, B.; Serra, V. Landscape planning and defragmentation measures: An assessment of costs and critical issues. Land Use Policy 2018, 72, 313-324. [CrossRef]

5. Battisti, C.; Romano, B. Frammentazione e Connettività. Dall'analisi Ecologica alla Pianificazione Ambientale; CittàStudi: Milano, Italy, 2007.

6. Astiaso Garcia, D.; Bruschi, D.; Cinquepalmi, F.; Cumo, F. An estimation of urban fragmentation of natural habitats: Case studies of the 24 italian national parks. Chem. Eng. Trans. 2013, 32, 49-54.

7. De Montis, A.; Caschili, S.; Mulas, M.; Modica, G.; Ganciu, A.; Bardi, A.; Ledda, A.; Dessena, L.; Laudari, L.; Fichera, C.R. Urban-rural ecological networks for landscape planning. Land Use Policy 2016, 50, 312-327. [CrossRef]

8. De Montis, A.; Ganciu, A.; Cabras, M.; Bardi, A.; Mulas, M. Comparative ecological network analysis: An application to Italy. Land Use Policy 2019, 81, 714-724. [CrossRef]

9. Fahrig, L. How much habitat is enough? Biol. Conserv. 2001, 100, 65-74. [CrossRef]

10. Driscoll, D.A.; Weir, T. Beetle responses to habitat fragmentation depend on ecological traits, habitat condition, and remnant size. Conserv. Biol. 2005, 19, 182-194. [CrossRef]

11. Feeley, K.J.; Terborgh, J.W. Direct versus indirect effects of habitat reduction on the loss of avian species from tropical forest fragments. Anim. Conserv. 2008, 11, 353-360. [CrossRef]

12. Council of the European Union. Council Directive 92/43/EEC of 21 May 1992 on the conservation of natural habitats and of wild fauna and flora. Off. J. Eur. Union 1992, 11, 0114.

13. European Parliament and Council of the European Union. Directive 2009/147/EC of the European Parliament and of the Council of 30 November 2009 on the conservation of wild birds. Off. J. Eur. Union 2010, 20, 7-25.

14. EEA. Natura 2000 Barometer Statistics. Available online: https:/www.eea.europa.eu/themes/biodiversity/ document-library/natura-2000/natura-2000-network-statistics/natura-2000-barometer-statistics/statistics/ barometer-statistics (accessed on 21 July 2019).

15. Italian Ministry of the Environment. ZSC Designate|Ministero dell'Ambiente e della Tutela del Territorio e del Mare. Available online: https://www.minambiente.it/pagina/zsc-designate (accessed on 14 July 2019).

16. Cannas, I.; Zoppi, C. Ecosystem Services and the Natura 2000 Network: A Study Concerning a Green Infrastructure Based on Ecological Corridors in the Metropolitan City of Cagliari. In Computational Science and Its Applications-ICCSA 2017, Proceedings of the 17th International Conference on Computational Science and Its Applications, Trieste, Italy, 3-6 July 2017; Gervasi, O., Murgante, B., Misra, S., Borruso, G., Torre, C.M., Rocha, A.M.A.C., Taniar, D., Apduhan, B.O., Stankova, E., Cuzzocrea, A., Eds.; Springer International Publishing: Cham, Switzerland, 2017; pp. 379-400.

17. Floris, M.; Ruggeri, D. Planning with Ecosystem Services in the Natura 2000 Network of the Metropolitan City of Cagliari. In Computational Science and Its Applications-ICCSA 2017, Proceedings of the 17th International Conference on Computational Science and Its Applications, Trieste, Italy, 3-6 July 2017; Gervasi, O., Murgante, B., Misra, S., Borruso, G., Torre, C.M., Rocha, A.M.A.C., Taniar, D., Apduhan, B.O., Stankova, E., Cuzzocrea, A., Eds.; Springer International Publishing: Cham, Switzerland, 2017; pp. 401-415.

18. Lai, S.; Zoppi, C. The Influence of Natura 2000 Sites on Land-Taking Processes at the Regional Level: An Empirical Analysis Concerning Sardinia (Italy). Sustainability 2017, 9, 259. [CrossRef]

19. Romano, B.; Zullo, F.; Fiorini, L.; Ciabò, S.; Marucci, A. Sprinkling: An Approach to Describe Urbanization Dynamics in Italy. Sustainability 2017, 9, 97. [CrossRef]

20. Romano, B.; Fiorini, L.; Zullo, F.; Marucci, A. Urban Growth Control DSS Techniques for De-Sprinkling Process in Italy. Sustainability 2017, 9, 1852. [CrossRef] 
21. Gonzalez-Abraham, C.E.; Radeloff, V.C.; Hammer, R.B.; Hawbaker, T.J.; Stewart, S.I.; Clayton, M.K. Building patterns and landscape fragmentation in northern Wisconsin, USA. Landsc. Ecol. 2007, 22, 217-230. [CrossRef]

22. Rafferty, J.P. Urban Sprawl-Description, Causes, Environmental Impacts, \& Alternatives. Available online: https://www.britannica.com/topic/urban-sprawl (accessed on 18 July 2019).

23. Saganeiti, L.; Favale, A.; Pilogallo, A.; Scorza, F.; Murgante, B. Assessing Urban Fragmentation at Regional Scale Using Sprinkling Indexes. Sustainability 2018, 10, 3274. [CrossRef]

24. Ledda, A.; De Montis, A.; Serra, V. The effect of buildings on landscape fragmentation in Natura 2000 sites. A quantitative and comparative assessment. In Proceedings of the INPUT aCAdemy Conference 2019, Cagliari, Italy, 24-26 June 2019; Federico II Open Access University Press: Napoli, Italy, 2019. (In press).

25. Autonomous Region of Sardinia. Sardegna Territorio-Paesaggio-Piano paesaggistico. 2006. Available online: http://www.sardegnaterritorio.it/paesaggio/pianopaesaggistico2006.html (accessed on 12 July 2019).

26. De Montis, A.; Ledda, A.; Serra, V. Rural buildings and landscape fragmentation: Measure and interpretation. In Proceedings of the 11th International AIIA Conference on "Biosystems Engineering Addressing the Human Challenges of the 21st Century", Bari, Italy, 5-8 July 2017; p. 17.

27. Horning, N.; Robinson, J.A.; Sterling, E.J.; Turner, W.; Spector, S. Remote Sensing for Ecology and Conservation: A Handbook of Techniques, 1st ed.; Oxford University Press: Oxford, NY, USA, 2010.

28. Sage. Encyclopedia of Geographic Information Science, 1st ed.; Kemp, K., Ed.; SAGE Publications Inc.: Los Angeles, CA, USA, 2007.

29. Miller-Rushing, A.J.; Primack, R.B.; Devictor, V.; Corlett, R.T.; Cumming, G.S.; Loyola, R.; Maas, B.; Pejchar, L. How does habitat fragmentation affect biodiversity? A controversial question at the core of conservation biology. Biol. Conserv. 2019, 232, 271-273. [CrossRef]

30. Hernando, A.; Velázquez, J.; Valbuena, R.; Legrand, M.; García-Abril, A. Influence of the resolution of forest cover maps in evaluating fragmentation and connectivity to assess habitat conservation status. Ecol. Indic. 2017, 79, 295-302. [CrossRef]

31. Piquer-Rodríguez, M.; Kuemmerle, T.; Alcaraz-Segura, D.; Zurita-Milla, R.; Cabello, J. Future land use effects on the connectivity of protected area networks in southeastern Spain. J. Nat. Conserv. 2012, 20, 326-336. [CrossRef]

32. Tomaselli, V.; Tenerelli, P.; Sciandrello, S. Mapping and quantifying habitat fragmentation in small coastal areas: A case study of three protected wetlands in Apulia (Italy). Environ. Monit. Assess. 2012, 184, 693-713. [CrossRef]

33. McGarigal, K.; Cushman, S.A.; Neel, M.C.; Ene, E. FRAGSTATS: Spatial Pattern Analysis Program for Categorical Maps. Computer Software Program; University of Massachusetts, Amherst: Amherst, MA, USA, 2002.

34. Radeloff, V.C.; Hammer, R.B.; Stewart, S.I. Rural and Suburban Sprawl in the U.S. Midwest from 1940 to 2000 and Its Relation to Forest Fragmentation. Conserv. Biol. 2005, 19, 793-805. [CrossRef]

35. Hansen, A.J.; Knight, R.L.; Marzluff, J.M.; Powell, S.; Brown, K.; Gude, P.H.; Jones, K. Effects of Exurban Development on Biodiversity: Patterns, Mechanisms, and Research Needs. Ecol. Appl. 2005, 15, 1893-1905. [CrossRef]

36. Theobald, D.M.; Miller, J.R.; Hobbs, N.T. Estimating the cumulative effects of development on wildlife habitat. Landsc. Urban Plan. 1997, 39, 25-36. [CrossRef]

37. Hansen, A.J.; Phillips, L.B. Insights from the Greater Yellowstone Ecosystem on Assessing Success in Sustaining Wildlands. In Climate Change in Wildlands: Pioneering Approaches to Science and Management; Hansen, A.J., Monahan, W.B., Olliff, S.T., Theobald, D.M., Eds.; Island Press/Center for Resource Economics: Washington, DC, USA, 2016; pp. 327-353.

38. McKenzie, P.; Cooper, A.; McCann, T.; Rogers, D. The ecological impact of rural building on habitats in an agricultural landscape. Landsc. Urban Plan. 2011, 101, 262-268. [CrossRef]

39. Sanna, A. Il Sulcis e L'Iglesiente, L'edilizia Diffusa e i Paesi; I Manuali di Recupero dei Centri Storici Della Sardegna; DEI: Cagliari, Italy, 2009.

40. Romano, B.; Zullo, F. Valutazione Della Pressione Insediativa: Indicatori e Sperimentazione di Soglie; Forum Editrice Universitaria Udinese: Udine, Italy, 2013.

41. Romano, B.; Tamburini, G. Urban Sensibility of Landscape Structures in Italy General Characteristics and Local Details. In Enlargement, Southern Europe and the Mediterranean, Proceedings of the 46th Congress of the European Regional Science Association, Volos, Greece, 30 August-3 September 2006; European Regional Science Association: Louvain-la-Neuve, Belgium, 2006. 
42. Jaeger, J.A.G. Landscape division, splitting index, and effective mesh size: New measures of landscape fragmentation. Landsc. Ecol. 2000, 15, 115-130. [CrossRef]

43. Jaeger, J.A.G. Improving Environmental Impact Assessment and Road Planning at the Landscape Scale. In Handbook of Road Ecology; John Wiley \& Sons Ltd.: Hoboken, NJ, USA, 2015; pp. 32-42.

44. ESRI. Average Nearest Neighbor-Help. ArcGIS Desktop. Available online: http://desktop.arcgis.com/en/ arcmap/10.3/tools/spatial-statistics-toolbox/average-nearest-neighbor.htm (accessed on 14 July 2019).

45. Brown, J.H.; Curtin, C.G.; Braithwaite, R.W. Management of the Semi-Natural Matrix. In How Landscapes Change: Human Disturbance and Ecosystem Fragmentation in the Americas; Bradshaw, G.A., Marquet, P.A., Eds.; Springer: Heidelberg/Berlin, Germany, 2003; pp. 327-343.

46. ESRI. How Average Nearest Neighbor Works-ArcGIS Pro. ArcGIS Desktop. Available online: https://pro.arcgis.com/en/pro-app/tool-reference/spatial-statistics/h-how-average-nearest-neighbordistance-spatial-st.htm (accessed on 24 July 2019).

47. Autonomous Region of Sardinia. Carte dell'uso del Suolo-Sardegna Geoportale. Available online: http://www.sardegnageoportale.it/index.php? xsl=2420\&s=40\&v=9\&c=14480\&es=6603\&na $=1 \& \mathrm{n}=$ 100\&esp $=1 \& t b=14401$ (accessed on 14 July 2019).

48. ISPRA. Dati del Sistema Informativo di Carta della Natura della regione Sardegna. Anno. 2013. Available online: http://www.isprambiente.gov.it/en/environmental-services/map-of-the-nature-system?set_ language $=$ en (accessed on 13 July 2019).

49. EEA. Access Information about Protected and Other Designated Sites Relevant for Fauna, Flora and Habitat Protection in Europe. Available online: https://eunis.eea.europa.eu/sites.jsp (accessed on 13 July 2019).

50. ESRI. About ArcGIS-Mapping \& Analytics Platform. Available online: https://www.esri.com/en-us/arcgis/ about-arcgis/overview (accessed on 13 July 2019).

51. Benvenuto in QGIS! Available online: https://qgis.org/it/site/ (accessed on 28 July 2019).

52. Microsoft. Microsoft Office 2010—Scarica Office 2010. Available online: https://products.office.com/it-it/ office-2010 (accessed on 13 July 2019).

53. European Commission. The Natura 2000 Biogeographical Regions_Environment-European Commission. Available online: https:/ec.europa.eu/environment/nature/natura2000/biogeog_regions/ (accessed on 14 August 2019).

54. Sundseth, K. Natura 2000 in the Mediterranean Region; European Commission Environment: Luxembourg, 2009.

55. Camarda, I.; Laureti, L.; Angelini, P.; Capogrossi, R.; Carta, L.; Brunu, A. Il Sistema Carta della Natura della Sardegna; ISPRA: Roma, Italy, 2015.

56. Grill, A.; Casula, P.; Lecis, R.; Menken, S. Endemism in Sardinia. In Phylogeography of Southern European Refugia: Evolutionary Perspectives on the Origins and Conservation of European Biodiversity; Weiss, S., Ferrand, N., Eds.; Springer Netherlands: Dordrecht, The Netherlands, 2007; pp. 273-296.

57. Ledda, A.; De Montis, A. Infrastructural landscape fragmentation versus occlusion: A sensitivity analysis. Land Use Policy 2019, 83, 523-531. [CrossRef]

58. Autonomous Region of Sardinia. Linee Guida per la Redazione dei Piani di Gestione dei SIC e ZPS; Regione Autonoma Della Sardegna: Sardinia, Italy, 2012.

59. BirdLife International 2018. Tetrax Tetrax. The IUCN Red List of Threatened Species 2018: E.T22691896A129913710. Available online: https://www.iucnredlist.org/en (accessed on 17 July 2019).

60. Autonomous Region of Sardinia. Piano di Gestione ZPS “Piana di Ozieri"-Avviata la Valutazione Ambientale Strategica-News Detail Valutazioni Ambientali. Available online: https://portal.sardegnasira.it/-/piano-digestione-zps-piana-di-ozieri-avviata-la-valutazione-ambientale-strategica (accessed on 25 July 2019).

61. Neri, M.; Menconi, M.E.; Vizzari, M.; Mennella, V.G.G. A proposal of a new methodology for best location of environmentally sustainable roads infrastructures. Validation along the Fabriano-Muccia road. Inf. Constr. 2010, 62, 101-112.

62. European Parliament and European Council. Directive 2001/42/EC of the European Parliament and of the Council of 27 June 2001 on the Assessment of the Effects of Certain Plans and Programmes on the Environment. Available online: https://eur-lex.europa.eu/legal-content/EN/ALL/?uri=CELEX\%3A32001L0042 (accessed on 16 August 2019). 
63. Söderman, T.; Saarela, S.-R. Biodiversity in strategic environmental assessment (SEA) of municipal spatial plans in Finland. Impact Assess. Proj. Apprais. 2010, 28, 117-133. [CrossRef]

64. Autonomous Region of Sardinia. Ricerca SIC, ZSC e ZPS. Available online: https://portal.sardegnasira.it/ ricerca-sic-zps (accessed on 13 July 2019). 